Sayed Naqibullah Mostafawi Wildlife Conservation Society, Afghanistan Program, Kabul, Afghanistan

JALALUDIN NASERI National Environmental Protection Agency, Kabul, Afghanistan

Stephane Ostrowski Wildlife Conservation Society, Afghanistan Program, Kabul, Afghanistan

E-mailsostrowski@wcs.org

\section{Urgent conservation of Buchanania barberi (Anacardiaceae) in Kerala, India}

The evergreen tree Buchanania barberi Gamble of the family Anacardiaceae is endemic to the South Western Ghats of Kerala, India. The first herbarium specimen of the species was collected in Nadarai, Thiruvananthapuram, in 1904 by C.A. Barber and the species was described by J.S. Gamble in 1916 (J.S. Gamble, 1916, Notes of the Flora of Madras. Kew Bulletin, 135). The species was categorized as Endangered in the Red Data Book of Indian Plants in 1990 and as Critically Endangered on the IUCN Red list in 1998. The species was rediscovered by staff of the Jawaharlal Nehru Tropical Botanic Garden and Research Institute (JNTBGRI) in the Palode region of Thiruvananthapuram in 2001 (Santhosh Kumar et al., 2002, Rheedea, 12, 197200). In 2005 the species was included in the national priority list of endangered plants.

In 2016 Botanic Gardens Conservation International, UK, made a grant to JNTBGRI to support research on this species. A total of 11 field surveys were carried out in the Palode region (c. $74 \mathrm{~m}$ altitude) from July 2016 to June 2017. Four individuals were recorded, of which two were adult and two were juvenile trees. The area of occupancy of the species is $<5 \mathrm{~km}^{2}$. This species has no clonal growth and propagates by seeds. Our surveys and information obtained from interviews with local people reveal: (1) low fruit production despite high levels of flowering (2) no record of establishment of seedlings, (3) consumption of the fruits by birds, (4) low seed germination as a result of dormancy and unfavourable conditions, and (5) the impact of development programmes in the area, especially road expansion.

Our research on seed collected in April 2017 indicates delayed germination with dormancy. Experimentation with methods to break dormancy and establish seedlings are being carried out. Further research and surveys are required in South Kerala, with the help of local forest range officers and taxonomists, to elucidate fully the conservation status of this rare and Critically Endangered species.

We acknowledge support from Botanic Gardens Conservation International, UK (grant no. A217).

Anurag Dhyani and C. Anilkumar Division of Conservation Biology, Jawaharlal Nehru Tropical Botanic Garden and
Research Institute, Thiruvananthapuram, Kerala, India E-mail anuragdhyani@gmail.com

\section{Missing monkey found: Vanzolini's bald-faced saki monkey Pithecia vanzolinii}

A recent revision of the taxonomy of the Neotropical saki monkeys (genus Pithecia) described a total of 16 species, including five new species (Marsh, L.K., 2014, Neotropical Primates, 21, 1-165). In the revision the only information on $P$. vanzolinii came from museum specimens, and it was the only saki for which there was no photographic evidence of living individuals. The holotype was collected by A.M. Olalla in 1936 in the Lago Grande region, south of the Rio Juru and west of the Rio Eiru in Amazonas state, Brazil, and until this reporting went undocumented there for nearly 80 years. Pithecia vanzolinii is currently categorized as Data Deficient on the IUCN Red List.

In January-February 2017 an expedition called Houseboat Amazon, co-organized by Global Conservation Institute, USA, and Mamirauá Sustainable Development Institute, Brazil, surveyed for large mammals, with a particular focus on primates, along the Rio Eiru and Igarapé Preto in Amazonas. We searched for P. vanzolinii in the location where it was originally collected, with the goal of determining its existence and to record behavioural, demographic, distribution, and habitat information for the species. The full scope of the project (January-May 2017) included assessment of hunting and fishing, habitat analysis, drone mapping, and photography of all encountered species in the major watersheds on the right bank of the Rio Jurua: Tarauacá, Eiru, Gregório, and Riozinho da Liberdade.

The region has three distinct forest types: várzea (seasonally whitewater-flooded), igapó (seasonally blackwater-flooded), and terra firme (forest that does not flood seasonally). Surveys were conducted on foot in terra firme, by small, motorized canoes in rivers and lakes, and by twoperson canoes in várzea and igapó. Local guides were employed to perform surveys with the research team. In January a two-person team conducted 10 surveys along Igarapé Preto (a total of 64 hours and $28 \mathrm{~km}$ ). In February a total of 35 surveys were conducted along the Rio Eiru by 68 investigators in 3-4 teams per day (a total 208 surveyhours and 240 survey-km).

Pithecia vanzolinii was observed in both flooded and unflooded forest, in multiple locations on both sides of the Rio Eiru, from the mouth of the Rio Jurua $40 \mathrm{~km}$ upriver to the border of the Terra Indígena Rio Eiru. We observed the species in the original collection locations: one sighting in the igapó of Lago Grande, three sightings in igapó and terra firme near Santo Antônio, and near the former village of Santa Cruz, with one sighting in the Lago Paris area. In Igarapé Preto and its contiguous igapó, we sighted the 
species on eight occasions in January and twice in February, and collected one voucher specimen, of an adult male, which is held in the mammal collection at Mamirauá Sustainable Development Institute (SISBIO no. 55085). On the Rio Eiru we sighted the species three times in terra firme, once along an igarapé, and twice in várzea/igapó. In total we made 21 sightings of 12 groups, with 2-5 individuals per group and a total of 34 individuals.

The most striking finding of the project was the intensity of hunting. Local people hunt for subsistence and for extended family living in the city of Eirunepé. Eirunepés urban inhabitants hunt, fish, extract wood and farm intensively in the flooded and unflooded forests along the Rio Eiru. Pithecia vanzolinii is hunted for food when larger species are unavailable. The primates preferred by hunters (species of Ateles, Alouatta, Sapajus and Cacajao) were encountered only eight times in total, making sakis the largest primate seen on most surveys. The conservation status of these primates outside reserves may become critical if hunting cannot be controlled.

L.K. Marsh, A. Duarte, J.P. Bueno Gomez, C. Selby, I. Batista DA SILVA and S. WHITAKER Global Conservation Institute, Santa Fe, New Mexico, USA

E-maillkmarsh@global-conservation.org

L.P. LEMOS and F. ENNES SILVA Mamirau Institute for Sustainable Development, Tefé, Amazonas, Brazil

M.I.S. Santana Universidade de Brasilia, Faculdade de Agronomia e Medicina Veterinaria, Brasilia, Distrito Federal, Brazil 